\title{
Transfer of Heightened Immunity to Skin Homografts by Lymphoid RNA*
}

\author{
John A. Mannick † and Richard H. Egdahl \\ (From the Strauss Surgical Research Laboratories and the Department of Surgery, \\ Medical College of Virginia, Richmond, Va.)
}

Prior studies from this laboratory have indicated that previously unstimulated lymph node cells may be altered to a state resembling transplantation immunity by incubation in vitro with ribonucleic acid (RNA) extracted from specifically sensitized lymph nodes $(2,3)$. The assay of transplantation immunity used in these experiments was the transfer reaction of Brent, Brown, and Medawar (4), which is a delayed inflammatory reaction in the skin produced by the intradermal injection of immune cells into the animal against which the anticipated immune response is directed. Our finding that lymphoid RNA from an immunized animal may confer upon otherwise unsensitized lymph node cells the capacity to produce a transfer reaction has been confirmed by Clarke and Wilson (5) and more recently by others $(6,7)$.

However, the transfer reaction may be criticized as a test for transplantation immunity. It is possible by gross inspection to confuse the transfer reaction with other less specific inflammatory responses in the skin. Moreover, while reports from Brent, Brown, and Medawar (4), from Dvorak and Waksman (8), and from this laboratory (2, $3,9)$ have demonstrated adequately the association between the production of a transfer reaction and the state of transplantation immunity, there is no conclusive evidence that the capacity to produce a transfer reaction is equivalent to the capacity to manifest transplantation immunity in

\footnotetext{
* Submitted for publication April 30, 1964; accepted July 16, 1964.

This work was supported in part by U. S. Public Health Service research grants AM-07495 and CA-05725 and by American Cancer Society grant T 166-B.

A report of a portion of this work was presented at the annual meeting of the Society of University Surgeons, Los Angeles, Calif., 1964 (1).

† Markle Scholar in Medical Sciences. Present address: Massachusetts Memorial Hospitals, Boston, Mass.
}

a more conventional manner, for example, by the rejection of tissue homografts. Therefore our present study was undertaken to determine whether or not heightened immunity to skin homografts could be transferred from one animal to another by RNA extracted from sensitized lymph nodes.

\section{Methods}

Outbred adult rabbits of three breeds, New Zealand white, California white, and Dutch, were used as experimental animals. The rabbits weighed from 1.5 to $3.5 \mathrm{~kg}$. They were caged individually in an air-conditioned animal room and maintained on a diet of Purina rabbit chow and water. The techniques of full thickness skin grafting, excision of lymph nodes and spleen, and preparation of lymphoid cell suspensions used in this laboratory have been described previously $(3,9)$. In the present experiments spleen and lymph node cell suspensions were prepared in Trowell's medium ${ }^{1}$ rather than the Eagle Hela medium used in previous studies.

The extraction of RNA from lymph node tissue by the cold phenol method has also been described $(3,9)$. In the present experiments the RNA extraction procedure was altered in the one respect that the lymph node homogenate was treated with sodium lauryl sulfate (added in a quantity sufficient to make a $0.1 \%$ concentration) at room temperature for 5 minutes before beginning the phenol extractions. The RNA preparation, 5 to $15 \mathrm{ml}$ in volume, was always used immediately after extraction and was made $0.7 \mathrm{M}$ with respect to sucrose and adjusted to $\mathrm{pH} 7.0$ to 7.4 before incubation with lymphoid cells. The concentration of RNA was determined by the optical density at $260 \mathrm{~m} \mu$ in a Beckman model DU spectrophotometer (10).

The lymphoid cells were collected by centrifugation at $500 \times g$ and resuspended in the RNA preparation for incubation. Incubation time was 15 minutes, and the temperature was $37^{\circ} \mathrm{C}$, maintained in a water bath After incubation the cells were flooded with approximately 4 vol of Trowell's medium containing polyvinylpyrrolidone (PVP), 10\% by weight. The cells were then collected by centrifugation at $500 \times g$, washed, and resuspended in Trowell's medium with $10 \%$ PVP.

\footnotetext{
1 Grand Island Microbiological Co., Grand Island, N. Y.
} 
A cell count was performed, and a cell viability determination was made by the dye exclusion method using $1 \%$ eosin-Y. All cell suspensions used in this study were more than $80 \%$ viable.

The survival of test skin homografts in these experiments was considered to have ended when they showed unequivocal gross signs of rejection: eschar formation, discoloration, infarction, loss of pliability, etc. In some experiments the entire skin homograft was removed as a biopsy 4 days after transplantation and was immediately fixed in $10 \%$ formalin for histologic examination.

\section{Results}

Control skin homografts. Full thickness skin homografts from a Dutch and from a California donor were simultaneously applied to opposite ears of a previously untreated New Zealand recipient. The survival of these control skin homografts is shown in Table $I$. It is apparent that the survival times of the California and Dutch control grafts were not significantly different, $\mathrm{p}>0.6$ by the $t$ test (11). In 13 of the 20 experiments, as an added control the spleen was removed from the New Zealand recipient at the time of skin grafting. A cell suspension was prepared from the spleen, and these autologous cells were infused intravenously back into the New

TABLE I

Survival of skin homografts: control rabbits

\begin{tabular}{|c|c|c|c|}
\hline \multirow{2}{*}{$\begin{array}{c}\text { Rabbit } \\
\text { no. }\end{array}$} & \multirow{2}{*}{$\begin{array}{c}\text { No. autol- } \\
\text { ogous } \\
\text { spleen } \\
\text { cells } \\
\text { injected } \\
\left(\times 10^{6}\right)\end{array}$} & \multicolumn{2}{|c|}{ Survival of skin homografts } \\
\hline & & Calif. & Dutch \\
\hline & & day & \\
\hline 1163 & & 8 & 8 \\
\hline 1171 & & 8 & 8 \\
\hline 1593 & & 7 & 7 \\
\hline 1599 & & 7 & 7 \\
\hline 1586 & & 6 & 8 \\
\hline 1788 & & 8 & 6 \\
\hline 1800 & & 7 & 7 \\
\hline 2012 & 200 & 7 & 7 \\
\hline 880 & 200 & 7 & 7 \\
\hline 2778 & 223 & 7 & 7 \\
\hline 2744 & 300 & 7 & 7 \\
\hline 2749 & 160 & 6 & 6 \\
\hline 2732 & 334 & 7 & 7 \\
\hline 2735 & 100 & 7 & 6 \\
\hline 2728 & 134 & 6 & 6 \\
\hline 2739 & 230 & 8 & 8 \\
\hline 2733 & 172 & 7 & 6 \\
\hline 2738 & 239 & 6 & 6 \\
\hline 2729 & 156 & 6 & 6 \\
\hline \multirow[t]{2}{*}{2726} & 177 & 8 & 7 \\
\hline & & Mean $=7.0 \pm 0.7 \mathrm{SD}$ & $6.9 \pm 0.8 \mathrm{SD}$ \\
\hline
\end{tabular}

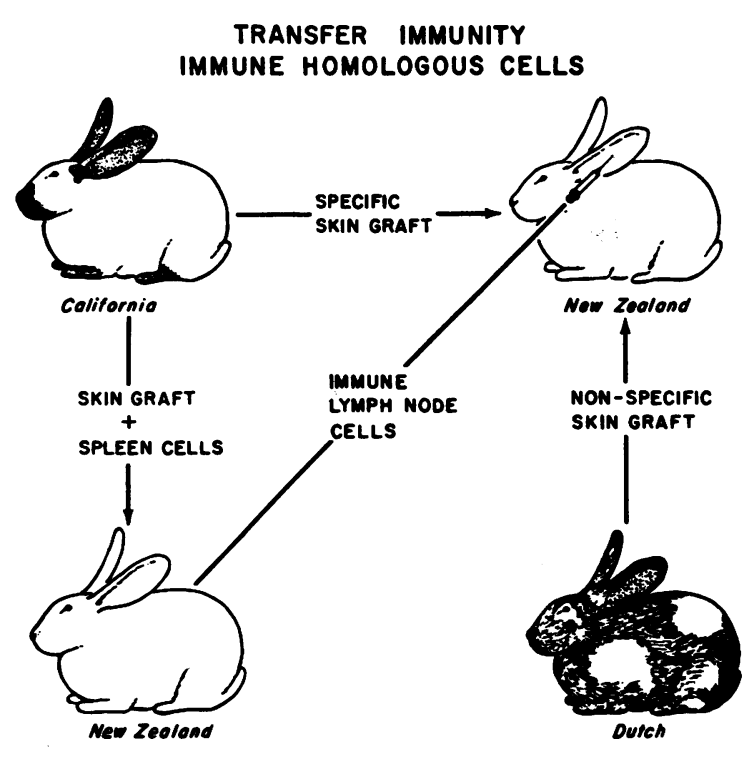

Fig. 1. Transfer of immunity with SEnSitized Homologous cells. A New Zealand recipient is immunized against a California donor by skin homografts applied to the hind legs and the chest wall and by injections of spleen cells into the foot pads. Eight days later the sensitized popliteal and axillary lymph nodes are excised, and a cell suspension is prepared from these nodes and infused intravenously into a second New Zealand animal, which in turn is challenged with a specific skin homograft from the original California donor and a nonspecific skin homograft from an indifferent Dutch rabbit (see text).

Zealand animal from which they had come. Evidently (Table I) autologous spleen cell infusion had no detectable effect on the survival of the control skin homografts.

Adoptive immunity controls. As a basis for comparison with future experimental groups, we attempted to transfer adoptive immunity to skin homografts with lymph node cells obtained from homologous immunized animals. The protocol used in this study is illustrated in Figure 1. A New Zealand recipient was immunized against a California donor by full thickness skin grafts applied to the lower hind legs and to opposite sides of the chest wall near the axillae. In addition a cell suspension was prepared from the donor spleen and injected into the four foot pads of the recipient. Eight days later, at the time of rejection of the skin homografts, the popliteal and axillary lymph nodes draining the homografts and the sites of spleen cell injection were excised. A cell suspension was prepared from these nodes 
TABLE II

Survival of skin homografts: immune homologous cells administered at the time of test grafting

\begin{tabular}{cccc}
\hline \hline & & \multicolumn{2}{c}{ Survival of skin homografts } \\
\cline { 3 - 4 } $\begin{array}{c}\text { Rabbit } \\
\text { no. }\end{array}$ & $\begin{array}{c}\text { No. cells } \\
\text { injected } \\
\left(\times 10^{6}\right)\end{array}$ & Specific Calif. & $\begin{array}{c}\text { Nonspecific } \\
\text { Dutch }\end{array}$ \\
\hline & & & days \\
2122 & 250 & 5 & 5 \\
2101 & 280 & 4 & 7 \\
2124 & 200 & 8 & 6 \\
2140 & 300 & 4 & 8 \\
2143 & 250 & 5 & 6 \\
2141 & 180 & 7 & 7 \\
2442 & 330 & 5 & 7 \\
2441 & 1,100 & 6 & 6 \\
2438 & 400 & 7 & 6 \\
2361 & 135 & 5 & 6 \\
2376 & 660 & & $6.5 \pm 0.8$ SD \\
& & Mean $=5.7 \pm 1.3$ SD & \\
\hline
\end{tabular}

and infused intravenously into a second New Zealand recipient that served as the test animal. This test rabbit then received a specific skin homograft from the original California donor applied to one ear and a nonspecific skin homograft from an indifferent Dutch donor applied to the opposite ear. In the initial group of such experiments the New Zealand test animals received the specific and nonspecific homografts immediately after the infusion of the immune homologous lymph node cells. The results are listed in Table II. The specific California homografts in this group of animals survived an average of $5.7 \pm$ 1.3 days, a time significantly shorter than the survival of first set California homografts in the control animals, $\mathrm{p}<0.01$, but not significantly shorter than the survival of the nonspecific Dutch homografts in the same test animals, $\mathrm{p}>0.1$.

TABLE III

Survival of skin homografts: immune homologous cells 48 hours after test grafting

\begin{tabular}{cccc}
\hline & & \multicolumn{2}{c}{ Survival of skin homografts } \\
\cline { 3 - 4 } $\begin{array}{c}\text { Rabbit } \\
\text { no. }\end{array}$ & $\begin{array}{c}\text { No. cells } \\
\text { injected } \\
\left(\times 10^{8}\right)\end{array}$ & Specific Calif. & $\begin{array}{c}\text { Nonspecific } \\
\text { Dutch }\end{array}$ \\
\hline & & \multicolumn{2}{c}{ days } \\
2434 & 705 & 5 & 7 \\
2433 & 935 & 5 & 7 \\
2325 & 1,110 & 5 & 5 \\
2488 & 105 & 6 & 8 \\
2374 & 450 & 4 & 5 \\
2359 & 260 & 5 & 6 \\
2370 & 560 & 5 & 5 \\
2470 & 850 & & \\
& & Mean $=5.1 \pm 0.6 \mathrm{SD}$ & $6.1 \pm 1.1 \mathrm{SD}$ \\
\hline
\end{tabular}

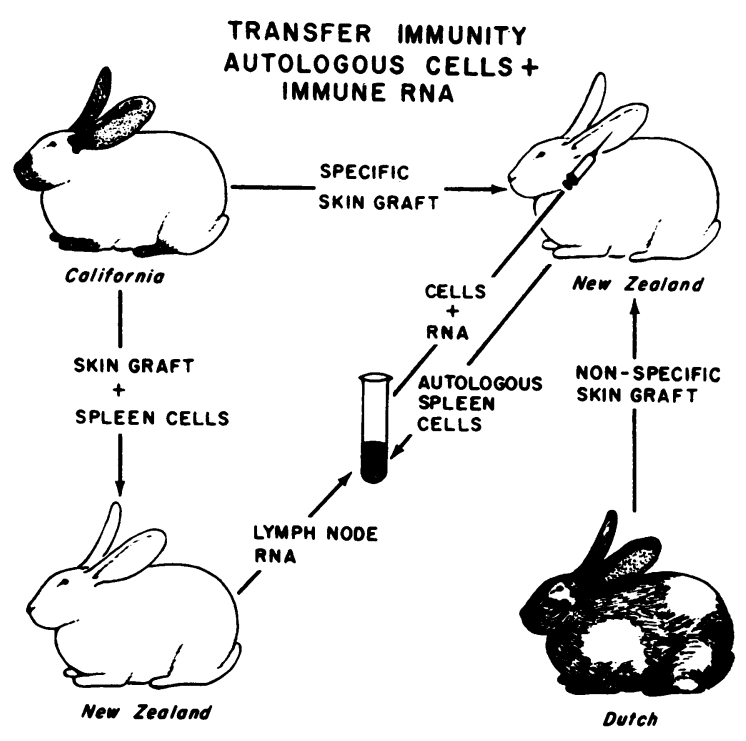

Fig. 2. Transfer of imMlenty with RNA-treated autologous cells. A New Zealand recipient is immunized against a California donor by skin homografts and injections of spleen cells into the foot pads. Eight days later the sensitized popliteal and axillary lymph nodes are excised. RNA is extracted from these nodes and is incubated in vitro with a suspension of spleen cells from a second New Zealand animal. These autologous spleen cells are then infused intravenously back into the New Zealand rabbit from which they came. This rabbit is in turn challenged with a specific skin homograft from the original California donor and a nonspecific skin homograft from an indifferent Dutch rabbit (see text).

The survival of these Dutch grafts was in turn not significantly shorter than the survival of Dutch homografts in control animals, $\mathrm{p}>0.2$.

As a check on the time relationships necessary for effective transfer of adoptive immunity, two further series of experiments were performed in

TABLE IV

Survival of skin homografts: immune homologous cells 48 hours before test grafting

\begin{tabular}{|c|c|c|c|}
\hline \multirow{2}{*}{$\begin{array}{l}\text { Rabbit } \\
\text { no. }\end{array}$} & \multirow{2}{*}{$\begin{array}{l}\text { No. cells } \\
\text { injected } \\
\left(\times 10^{6}\right)\end{array}$} & \multicolumn{2}{|c|}{ Survival of skin homografts } \\
\hline & & Specific Calif. & $\begin{array}{l}\text { Nonspecific } \\
\text { Dutch }\end{array}$ \\
\hline & & \multicolumn{2}{|c|}{ days } \\
\hline 2440 & 690 & 7 & 8 \\
\hline 2489 & 490 & 6 & 6 \\
\hline 2480 & 555 & 6 & 7 \\
\hline 2483 & 380 & 6 & 5 \\
\hline 2464 & 200 & 4 & 7 \\
\hline \multirow[t]{2}{*}{2469} & 710 & 8 & 8 \\
\hline & & Mean $=6.2 \pm 1.3 \mathrm{~S}$ & $6.8 \pm 1.2 \mathrm{SD}$ \\
\hline
\end{tabular}


TABLE V

Survival of skin homografts: autologous cells plus immune RNA administered at time of test grafting

\begin{tabular}{|c|c|c|c|c|}
\hline \multirow{2}{*}{$\begin{array}{c}\text { Rabbit } \\
\text { no. }\end{array}$} & \multirow{2}{*}{$\begin{array}{l}\text { No. cells } \\
\text { injected } \\
\left(\times 10^{6}\right)\end{array}$} & \multirow{2}{*}{$\begin{array}{l}\text { Concentration } \\
\text { of RNA in } \\
\text { incubation } \\
\text { medium }\end{array}$} & \multicolumn{2}{|c|}{ Survival of skin homografts } \\
\hline & & & Specific Calif. & Nonspecific Dutch \\
\hline \multirow{16}{*}{$\begin{array}{r}1156 \\
1167 \\
1939 \\
1936 \\
1427 \\
1535 \\
1592 \\
1541 \\
1795 \\
884 \\
886 \\
2008 \\
789 \\
2011\end{array}$} & & $\mu g / m l$ & & \\
\hline & 35 & 250 & 8 & 8 \\
\hline & 470 & 290 & 7 & 7 \\
\hline & 120 & 240 & 6 & 8 \\
\hline & 115 & 170 & 5 & 7 \\
\hline & 300 & 400 & 6 & 6 \\
\hline & 230 & 360 & 5 & 7 \\
\hline & 110 & 140 & 5 & 8 \\
\hline & 250 & 190 & 4 & 7 \\
\hline & 250 & 180 & 5 & 7 \\
\hline & 280 & 410 & 4 & 7 \\
\hline & 220 & 250 & 6 & 7 \\
\hline & 160 & 150 & 6 & 8 \\
\hline & 185 & 350 & 6 & 7 \\
\hline & 160 & 310 & 3 & 7 \\
\hline & & & Mean $=5.4 \pm 1$. & $7.2 \pm 0.5 \mathrm{SD}$ \\
\hline
\end{tabular}

which the specific California and nonspecific Dutch homografts were placed on the test animal either 48 hours before or 48 hours after the infusion of immune homologous lymph node cells. The results of these series of experiments are listed in Tables III and IV.

The survival of the specific California skin homografts in the animals grafted 48 hours before the infusion of the immune cells averaged $5.1 \pm 0.6$ days, a time very significantly shorter than the survival of first set California homografts in the control animals, $\mathrm{p}<0.001$, and significantly shorter than the survival of nonspecific Dutch homografts in the same animals, $\mathrm{p}<0.05$. On the other hand, the survival of specific California homografts in the recipients grafted 48 hours after the infusion of immune homologous cells averaged $6.2 \pm 1.3$ days, a time not significantly different from the survival of first set California homografts in control animals, $\mathrm{p}>0.1$, and a time not significantly different from the survival of nonspecific Dutch skin homografts in the same test animals, $p>0.4$. Apparently adoptive immunity to skin homografts was most effectively transferred in rabbits by immune homologous cells infused 48 hours after the application of the test skin homografts, and the immune cells were ineffective when administered 48 hours before test skin grafting.

Effect of autologous spleen cells incubated with immune $R N A$. The protocol followed in this and subsequent experiments is illustrated in Figure 2. As in the preceding experiments a New Zealand recipient was immunized against a California donor by skin homografts and injections of spleen cells into the foot pads. Again after 8 days the stimulated axillary and popliteal lymph nodes were excised. In this case, however, RNA was extracted from these lymph nodes. The RNA preparation was then incubated in vitro with a suspension of spleen cells obtained from a second New Zealand animal. After incubation the cells were collected, washed, resuspended, and injected intravenously back into the New Zealand rabbit from which they had come. This rabbit served as the test animal and immediately received a specific skin homograft from the original California donor and a nonspecific skin homograft from an indifferent Dutch rabbit.

The survival of the test skin homografts is shown in Table V. The average survival of the specific California homografts in these experiments was $5.4 \pm 1.3$ days, a time quite significantly shorter than the survival of first set California homografts in control animals, $p<0.001$, and a time very significantly shorter than the survival of the nonspecific Dutch homografts in the same test animals, $\mathrm{p}<0.001$. Within the dose range employed in these experiments there did not appear to be any correlation between the number of autologous spleen cells administered or the concentration of RNA in the incubation mixture and 
TABLE VI

Survival of skin homografts: autologous cells plus immune RNA-RNase* effect

\begin{tabular}{|c|c|c|c|c|}
\hline \multirow{2}{*}{$\begin{array}{l}\text { Rabbit } \\
\text { no. }\end{array}$} & \multirow{2}{*}{$\begin{array}{c}\text { No. cells } \\
\text { injected } \\
\left(\times 10^{6}\right)\end{array}$} & \multirow{2}{*}{$\begin{array}{c}\text { Concentration } \\
\text { of RNA in } \\
\text { incubation } \\
\text { medium }\end{array}$} & \multicolumn{2}{|c|}{ Survival of skin homografts } \\
\hline & & & Specific Calif. & Nonspecific Dutch \\
\hline & & $\mu g / m l$ & \multicolumn{2}{|c|}{ days } \\
\hline 2786 & 265 & 310 & 7 & 6 \\
\hline 2016 & 160 & 180 & 7 & 6 \\
\hline 877 & 165 & 280 & 7 & 7 \\
\hline 2017 & 200 & 270 & 6 & 7 \\
\hline 2025 & 180 & 215 & 8 & 9 \\
\hline 2345 & 360 & 295 & 7 & 9 \\
\hline 2330 & 320 & 260 & 9 & 6 \\
\hline 2332 & 235 & 320 & 6 & 7 \\
\hline \multirow[t]{2}{*}{2788} & 120 & 310 & 6 & 6 \\
\hline & & & Mean $=7.0 \pm 1.0$ & $7.0 \pm 1.2 \mathrm{SD}$ \\
\hline
\end{tabular}

${ }^{*} \mathrm{RNase}=$ five times recrystallized bovine pancreatic ribonuclease .

the results observed. However, on an empirical basis $200 \times 10^{6}$ or more spleen cells were infused whenever possible, and we attempted to keep the concentration of RNA in the incubation medium greater than $100 \mu \mathrm{g}$ per $\mathrm{ml}$.

Effect of ribonuclease. In this series of experiments a New Zealand recipient was again inmmunized against a California donor, and RNA was again extracted from the stimulated lymph nodes. Incubation with a spleen cell suspension from a second New Zealand animal was carried out as before except that at the time of incubation five times recrystallized bovine pancreatic ribonuclease $^{2}$ (RNase), at a concentration of $15 \mu \mathrm{g}$ per $\mathrm{ml}$, was added to the incubation medium. After incubation the cells were again collected, washed, and injected intravenously back into the New Zealand animal from which they had come. This rabbit then served as the test ani-

2 Worthington Biochemicals Corp., Freehold, N. J. mal and received simultaneous skin homografts from the original California donor and from an indifferent Dutch rabbit as before. As shown in Table VI the average survival of the specific California homografts in this series of experiments was $7.0 \pm 1.0$ days, a time not significantly different from the survival of first set California homografts in control animals, $p=1.0$, and a time also not significantly different from the survival of nonspecific Dutch homografts in the same test animals, $\mathrm{p}=1.0$. The addition of RNase to the RNA preparation at the time of incubation therefore apparently prevented the transfer of immunity observed in the preceding experiments. Prior work from this laboratory had provided assurance that RNase at concentrations lower than $50 \mu \mathrm{g}$ per $\mathrm{ml}$ would not affect the immunologic capacity of the lymphoid cells themselves $(9,12)$. The inability of RNase-treated cells to produce transfer reactions, as reported by others (13), was noted

TABLE VII

Survival of skin homografts: immune RNA alone intravenously

\begin{tabular}{|c|c|c|c|c|}
\hline \multirow{2}{*}{$\begin{array}{c}\text { Rabbit } \\
\text { no. }\end{array}$} & \multirow{2}{*}{$\begin{array}{l}\text { Volume } \\
\text { injected }\end{array}$} & \multirow{2}{*}{$\begin{array}{c}\text { Concentration } \\
\text { of RNA }\end{array}$} & \multicolumn{2}{|c|}{ Survival of skin homografts } \\
\hline & & & Specific Calif. & Nonspecific Dutch \\
\hline & $m l$ & $\mu g / m l$ & \multicolumn{2}{|c|}{ days } \\
\hline 2600 & 6 & 335 & 7 & 6 \\
\hline 2585 & 5 & 450 & 7 & 7 \\
\hline 2587 & 8 & 550 & 8 & 7 \\
\hline 2586 & 6 & 380 & 6 & 6 \\
\hline 2081 & 9 & 500 & 5 & 6 \\
\hline \multirow[t]{2}{*}{2104} & 15 & 205 & 7 & 7 \\
\hline & & & Mean $=6.7 \pm 1.0$ & $6.5 \pm 0.5 \mathrm{SD}$ \\
\hline
\end{tabular}


TABLE VIII

Survival of skin homografts: autologous cells plus immune RNA 48 hours before test grafting

\begin{tabular}{|c|c|c|c|c|}
\hline \multirow{2}{*}{$\begin{array}{c}\text { Rabbit } \\
\text { no. }\end{array}$} & \multirow{2}{*}{$\begin{array}{l}\text { No. cells } \\
\text { injected } \\
\left(\times 10^{6}\right)\end{array}$} & \multirow{2}{*}{$\begin{array}{l}\text { Concentration } \\
\text { of RNA in } \\
\text { incubation } \\
\text { medium }\end{array}$} & \multicolumn{2}{|c|}{ Survival of skin homografts } \\
\hline & & & Specific Calif. & Nonspecific Dutch \\
\hline \multirow{3}{*}{$\begin{array}{l}2337 \\
2350 \\
2777 \\
2789 \\
2800 \\
2794 \\
2796\end{array}$} & & $\mu g / m l$ & & \\
\hline & $\begin{array}{l}210 \\
195 \\
125 \\
245 \\
300 \\
160 \\
150\end{array}$ & $\begin{array}{l}410 \\
245 \\
350 \\
450 \\
110 \\
130 \\
500\end{array}$ & $\begin{array}{l}7 \\
7 \\
9 \\
8 \\
7 \\
6 \\
7\end{array}$ & $\begin{array}{l}6 \\
8 \\
8 \\
7 \\
8 \\
6 \\
7\end{array}$ \\
\hline & & & Mean $=7.3 \pm 0.9$ & $7.1 \pm 0.9 \mathrm{SD}$ \\
\hline
\end{tabular}

only after exposure of the cells to very high concentrations of RNase.

Effect of RNA alone intravenously. In this series of experiments a New Zealand recipient was immunized against a California donor as before. RNA was extracted from the sensitized lymph nodes and was then injected directly intravenously into a second New Zealand animal. This rabbit served as the test animal and received a specific skin homograft from the original California donor and a nonspecific homograft from an indifferent Dutch rabbit. The average survival of the specific California homografts in these experiments was $6.7 \pm 1.0$ days (Table VII). This time was not significantly different from the survival of first set California homografts in control animals, $\mathrm{p}>0.5$, and was also not significantly different from the survival of the nonspecific Dutch homografts in the same test animals, $\mathrm{p}>0.6$.

Autologous spleen cells incubated with immune RNA 48 hours before and 48 hours after grafting.
To clarify the time relationships involved in the apparent transfer of immunity with RNA-treated autologous cells, two further series of experiments were carried out. In the first series lymph nodes were excised as before from a New Zealand recipient rabbit immunized against a California donor. RNA was again extracted from these lymph nodes and incubated in vitro with a suspension of spleen cells from a second New Zealand animal. After incubation the autologous spleen cells were infused intravenously back into the New Zealand animal from which they had come. This rabbit served as the test animal and, in this case, received a specific skin homograft from the original California donor and a nonspecific homograft from an indifferent Dutch rabbit, applied 48 hours after the administration of the autologous spleen cells incubated with RNA. The average survival time of the specific California grafts was $7.3 \pm 0.9$ days (Table VIII), a time not significantly different from the survival of first set California grafts in control

TABLE IX

Survival of skin homografts: autologous cells plus immune RNA 48 hours after test grafting

\begin{tabular}{ccccc}
\hline \hline $\begin{array}{c}\text { Rabbit } \\
\text { no. }\end{array}$ & $\begin{array}{c}\text { No. cells } \\
\text { injected } \\
\left(\times 10^{6}\right)\end{array}$ & $\begin{array}{c}\text { Concentration } \\
\text { of RNA in } \\
\text { incubation } \\
\text { medium }\end{array}$ & \multicolumn{2}{c}{ Survival of skin homografts } \\
\cline { 3 - 5 } 2731 & 250 & $\mu g / m l$ & Specific Calif. & days \\
2073 & 200 & 250 & 6 & 6 \\
2030 & 290 & 460 & 5 & 6 \\
2037 & 380 & 225 & 5 & 7 \\
2044 & 310 & 310 & 4 & 6 \\
2026 & 280 & 550 & 4 & 6 \\
2027 & 185 & 220 & 4 & $6.6 \pm 0.8 \mathrm{SD}$ \\
\hline
\end{tabular}


TABLE $X$

Survival of skin homografts: autologous cells plus nonspecific $R N A$

\begin{tabular}{|c|c|c|c|c|}
\hline \multirow{2}{*}{$\begin{array}{c}\text { Rabbit } \\
\text { no. }\end{array}$} & \multirow{2}{*}{$\begin{array}{l}\text { No. cells } \\
\text { injected } \\
\left(\times 10^{8}\right)\end{array}$} & \multirow{2}{*}{$\begin{array}{l}\text { Concentration of } \\
\text { RNA in incuba- } \\
\text { tion medium }\end{array}$} & \multicolumn{2}{|c|}{ Survival of skin homografts } \\
\hline & & & Specific Calif. & Nonspecific Dutch \\
\hline \multirow{8}{*}{$\begin{array}{l}2447 \\
2437 \\
2315 \\
2323 \\
2476 \\
2487\end{array}$} & & $\mu g / m l$ & day & \\
\hline & 335 & Not recorded & 6 & 7 \\
\hline & 225 & Not recorded & 8 & 7 \\
\hline & 500 & 500 & 6 & 7 \\
\hline & 420 & 500 & 7 & 7 \\
\hline & 325 & 260 & 6 & 7 \\
\hline & 385 & 230 & 8 & 6 \\
\hline & & & Mean $=6.8 \pm 1.0 \mathrm{SD}$ & $6.8 \pm 0.4 \mathrm{SD}$ \\
\hline
\end{tabular}

animals, $\mathrm{p}>0.4$, and a time not significantly different from the survival of nonspecific Dutch homografts in the same test animals, $p>0.7$.

In a second series of experiments, after immunization of the New Zealand recipient by a California donor, RNA was extracted from the sensitized lymph nodes and incubated with spleen cells from a second New Zealand recipient as before. The autologous spleen cells were infused back into the New Zealand animal from which they had come. This rabbit served as the test animal and, in this case, had received a specific skin homograft from the original California donor and a nonspecific homograft from an indifferent Dutch rabbit 48 hours before the infusion of RNA-treated spleen cells. The survival of the specific California homografts in this series of experiments averaged $4.6 \pm 0.8$ days (Table IX). This time was very significantly different from the survival of first set California grafts in control animals, $\mathrm{p}<0.001$, and was also quite significantly different from the survival of the nonspecific Dutch homografts in the same test animals, $\mathrm{p}<0.001$.

Therefore autologous spleen cells incubated in vitro with immune RNA were apparently effective in transferring immunity when administered 48 hours after test grafting but were ineffective when administered 48 hours before grafting.

Effect of nonspecific RNA. In a further series of experiments the popliteal and axillary lymph nodes of a New Zealand animal were stimulated by three injections of $25 \mathrm{mg}$ of bovine serum albumin $(B S A)^{3}$ in Freund's complete adjuvant into the foot pads at 48-hour intervals. Seven days after the first injection the lymph nodes

3 Nutritional Biochemicals, Cleveland, Ohio. were excised, and RNA was extracted from these nodes and incubated in vitro with a spleen cell suspension from a second New Zealand animal. After incubation the spleen cells were infused intravenously back into the animal from which they had come. This New Zealand rabbit then served as the test animal and received a California skin homograft and a Dutch skin homograft applied simultaneously to opposite ears. The results are illustrated in Table X. The survival of the California skin homografts in this series of animals averaged $6.8 \pm 1.0$ days, a time not significantly different from the survival of first set California grafts in control animals, $p>0.6$, and a time not significantly different from the survival of Dutch skin homografts in the same test animals, $\mathrm{p}=1.0$.

Histologic confirmation. To obtain histologic confirmation of the gross impression of skin graft rejection obtained in the preceding studies, a final series of six experiments was performed. As before, a New Zealand recipient was immunized against a California donor, and RNA was extracted from the sensitized lymph nodes and incubated in vitro with spleen cells from a second New Zealand rabbit. After incubation the autologous cells were reinfused into the New Zealand rabbit from which they had come. This rabbit served as the test animal and had received a specific skin homograft from the original California donor and a nonspecific skin homograft from an indifferent Dutch rabbit 48 hours before the infusion of the autologous cells incubated with immune RNA. Forty-eight hours later, i.e., 4 days after the application of the homografts, both the specific and nonspecific homografts were excised in toto and processed for histologic examination. 
As a control a similar series of six New Zealand animals received simultaneous California and Dutch homografts without further treatment. Four days after grafting, both homografts were excised and processed for histologic examination.

As illustrated in Figure 3, the California and Dutch homografts excised from five of the six control animals demonstrated only minimal epithelial destruction 4 days after grafting. One unusual control animal had destroyed more than $50 \%$ of the epithelium in both the California and the Dutch grafts 4 days after grafting. In the series of six animals that received RNA-treated autologous spleen cells 48 hours after grafting, the specific California grafts showed from 75 to $100 \%$ destruction of the epithelium in four instances (Figure 3), from 50 to $75 \%$ destruction of the epithelium in one instance, and less than $50 \%$ destruction of the epithelium in only one instance. The nonspecific Dutch homografts in these six animals showed only minimal epithelial destruction.

\section{Discussion}

The present results appear to indicate that heightened immunity to skin homografts may be transferred by autologous lymphoid cells incubated in vitro with homologous RNA extracted from the lymph nodes of an immunized animal. The mechanism through which this apparent transfer of immunity is accomplished is obviously of considerable importance. The possibility that the transfer is mediated by cell-bound or cellcontained antibody, similar to that recently described by Najarian and Feldman (14), must be considered. Certainly the RNA preparation used in this laboratory is not free of protein contamination (9), and it is conceivable that antibodylike material might have been released from the disrupted lymphoid cells during extraction of the RNA, although considerable denaturation of this material would be expected during the multiple phenol extractions used in preparing the RNA. More compelling evidence that contaminating antibody did not play a major role in the transfer of immunity is afforded by the fact that the RNA preparation was ineffective when administered alone, without prior incubation in vitro with autologous lymphoid cells, and by the ability of low concentrations of purified RNase to prevent the transfer of immunity.

Consideration must also be given to the possibility that the heightened immunity observed in our experiments may have been caused by sensitization of the test animal by transplantation antigenic material contaminating the RNA preparation. Nester, Mäkelä, and Nossal (15) have presented convincing evidence that antigen may be included with nucleoprotein extracted from lymph nodes engaged in antibody formation. However, that sensitization by contaminating antigen did not produce the heightened immunity observed in the present experiments is indicated by the fact that autologous lymphoid cells incubated with the RNA preparation were ineffective in transferring immunity when administered 48 hours before test skin grafting but were effective when administered at the same time as, or 48 hours after, the application of the test grafts. Certainly, if direct stimulation by contaminating antigen had induced the heightened immune response, administration 48 hours before test grafting should have permitted greater sensitization of the test animals than later injection of the same material. Similarly, although the chemical nature of transplantation antigens in most species is unclear, mouse transplantation antigens $(16,17)$ and the transplantation antigenic material recently obtained from rabbit cells in this laboratory (18) are insensitive to RNase at concentrations far higher than those which effectively inhibited the transfer of immunity in the present experiments.

Finally the possibility must be considered that the heightened immunity we observed might be a nonspecific result of the exposure of immune competent cells to RNA or its breakdown products during incubation in vitro. That this is not the case, however, is suggested by the specificity of the heightened immune response. The survival of the nonspecific homografts was not detectably affected. Furthermore, nonspecific RNA, extracted from lymph nodes stimulated with BSA and adjuvant, was ineffective in producing accelerated rejection of skin homografts. We have, therefore, tentatively concluded that RNA extracted from sensitized lymph nodes was able to transfer to previously unstimulated lymphoid cells the ability to produce a specific immune response. 

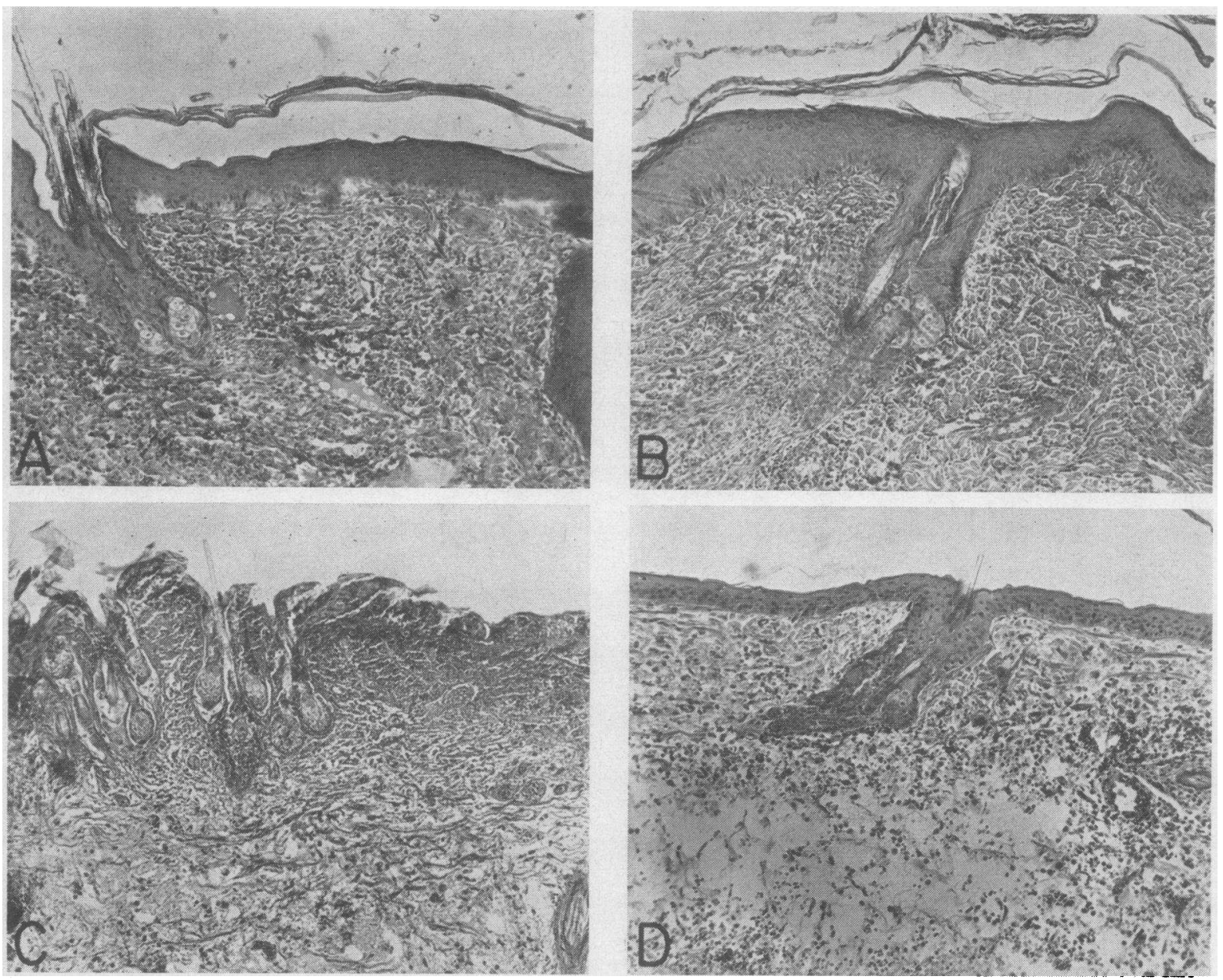

Fig. 3. Photomicrographs of California (A) and Dutch (B) Skin homografts excised from a control New Zealand Rabbit 4 days after Grafting. The epithelium of both grafts appears viable. This histologic picture is contrasted with that of a specific California homograft (C) excised 4 days after grafting from a New Zealand test animal that had received RNA-treated autologous spleen cells (see text). The epithelium of this specific homograft has been completely destroyed. The epithelium of a nonspecific Dutch homograft (D), also excised on the fourth day from the same New Zealand test animal, appears entirely viable. (Hematoxylin and eosin $\times 140$.)

Metabolic events involved in this transfer are as yet entirely undeciphered; however, it is conceivable that the effects observed may be the result of the addition of a form of "messenger" RNA (19) to the lymphoid cells and the subsequent synthesis of cell-bound antibody directed by this RNA molecule.

It is of interest that autologous spleen cells, incubated with immune homologous RNA, appeared to be somewhat more effective in transferring immunity than homologous immune cells. This difference very likely reflects the inevitable destruction of the injected homologous cells by the transplantation immune response of the test ani- mal. The difficulties involved in transferring adoptive immunity with immune competent cells in animals that are not members of the same inbred strain are well known (20-22). However, the fact that a detectable transfer of immunity was observed when immune homologous cells were used in the present experiments is not surprising, since Warwick, Archer, and Good (23) were able to transfer delayed hypersensitivity to streptokinase in the rabbit with similar numbers of immune, homologous cells, administered intravenously.

Consideration must be given to the effect of the time of administration of the cells upon the 
results obtained in the present studies. Both in the control experiments employing immune homologous cells and in the experiments in which autologous cells treated with immune RNA were used, a detectable transfer of immunity was observed when the cells were administered at the same time as the test grafts were applied, and a slightly greater effect was seen when the cells were administered 48 hours after grafting. However, administration of immune homologous cells or RNA-treated autologous cells 48 hours before skin grafting produced no detectable effect. These results are in contradistinction to those obtained in the mouse by Billingham, Brent, and Medawar (20). These investigators found that adoptive immunity to skin homografts could be transferred by immune, isologous lymphoid cells administered 3 days before grafting or at the same time as the test grafts were applied. The isologous cells were much less effective, however, when administered 48 hours after grafting. The reason for the difference between these results and the present findings is unclear; however, it is possible that the period of time during which RNAtreated autologous cells and homologous cells are capable of demonstrating detectable immune competence may be different from that during which immune isologous cells are effective. Moreover species variation may be responsible for differences between the mouse and the rabbit with regard to the time during which newly applied homografts are maximally susceptible to immune attack.

The present experiments are obviously closely allied to the recent work of Fishman and Adler (24), who have shown that RNA extracted from phage sensitized rat macrophages can, upon incubation with previously unsensitized lymphoid cells, induce in these cells the capacity to form specific antiphage antibody. Also, in parallel with work from this laboratory (9), Fishman, Hammerstrom, and Bond (25) have shown that tritium-labeled RNA extracted from macrophages is incorporated by lymphoid cells during incubation in vitro, and more recently, Fishman (26) has reported that systemic administration of his RNA preparation is ineffective in inducing antibody synthesis in test animals, whereas administration of the RNA in Millipore diffusion cham- bers is effective, presumably because the RNA in the latter case is taken up by the lymphoid cells that surround the chambers before it can be destroyed by the ribonuclease in the tissue fluids and plasma.

The present RNA preparation also may be closely related to the "transfer factor" of Lawrence and co-workers $(27,28)$. Transfer factor as defined by these investigators is a subcellular fraction derived from the circulating blood leukocytes of humans which, upon injection into a homologous individual, has the capacity to transfer various types of delayed hypersensitivity including a heightened immunity to skin homografts. In this respect transfer factor resembles the present RNA preparation, and in addition there is now evidence suggesting that transfer factor is a small polynucleotide possibly associated with polypeptide (29). Nevertheless, important differences remain, since the present RNA preparation, as opposed to transfer factor, is ineffective when administered alone, without prior incubation with lymphoid cells, and is sensitive to RNase. On the other hand, the small size of the molecule isolated by Lawrence and associates (29) may account for the well-known resistance of their material to RNase. Thus this resistance may be a fortuitous result of species variation and may explain the many failures to reproduce Lawrence's work in experimental animals (27). The present results and the studies of Fishman noted above would suggest that the capacity to transfer certain types of immunity with an RNA fraction derived from lymphoid cells may be a phenomenon more widespread among mammalian species than was previously supposed. The recent investigations of Fong, Chin, and Vickrey (30) indicate, however, that the transfer of cellular resistance to tubercle bacilli with an RNase sensitive subcellular fraction is much less easily accomplished in the guinea pig than in other mammalian species, notably the rabbit. The guinea pig has previously been the animal most widely used in the experimental study of hypersensitivity.

Finally, the present work has obvious implications for the investigation of tumor immunity. Woodruff and Symes (22) have recently summarized the evidence suggesting that many neo- 
plasms may be more susceptible to immunological destruction by immune competent cells than by circulating antibody. However, attempts to transfer adoptive or cellular immunity to tumors have been largely confined to experimental situations in which the donor and recipient of the cells were members of the same inbred animal strain (22). Otherwise the transferred, immune competent cells may be quickly destroyed by the transplantation immune response of the new host and may themselves mount a destructive immunologic attack against the host tissues. The present results suggest a possible solution to these problems through the use of autologous lymphoid cells incubated in vitro with immune homologous or heterologous RNA.

Nevertheless, the establishment of such a system of immune transfer might first require the isolation of tumor specific antigens, obviously a formidable undertaking. Moreover the therapeutic significance of this proposed transfer of cellular immunity to tumors would very likely depend upon the ability of the transferred immune state to become self replicating. Although there is evidence that the transfer factor of Lawrence and co-workers may possess this quality, at least with respect to the transfer of delayed allergy to bacterial antigens (27), there is no indication from the present study that the immune response produced by RNA-treated autologous cells is anything but short lived. Further investigation of this question will be necessary, however, before a definite conclusion may be drawn.

\section{Summary}

1. Adoptive immunity to skin homografts from a California white donor was transferred to previously unsensitized New Zealand white rabbits by the intravenous infusion of homologous lymph node cells obtained from a second New Zealand animal immunized against the same California donor.

2. Heightened immunity to skin homografts from a California donor was also transferred to New Zealand rabbits by the intravenous administration of autologous spleen cells incubated in vitro with homologous RNA extracted from the lymph nodes of a second New Zealand animal immunized against the same California donor. Im- munity thus transferred was apparently specific for the tissues of the California donor, since the survival of nonspecific Dutch homografts in the same New Zealand test animals was not affected.

3. The transfer of immunity by the RNAtreated lymphoid cells was abolished by exposure of the RNA preparation to small amounts of ribonuclease.

4. The RNA preparation was ineffective in transferring immunity when administered directly intravenously without prior incubation in vitro with lymphoid cells.

5. Autologous lymphoid cells, incubated with RNA extracted from lymph nodes stimulated against a protein antigen, were ineffective in inducing the accelerated rejection of skin homografts.

6. RNA-treated, autologous lymphoid cells and immune, homologous lymphoid cells were effective in transferring immunity to skin homografts when infused at the same time as the test grafts were applied or when administered 48 hours after grafting. Neither the homologous cells nor the RNA-treated autologous cells produced a detectable effect when administered 48 hours before the application of the test grafts.

\section{Acknowledgment}

The authors gratefully acknowledge the expert technical assistance of Mr. Farley Moxley and Mrs. Florine Booth.

\section{References}

1. Mannick, J. A. Transfer of "adoptive" immunity to homografts by RNA. A preliminary report. Surgery 1964, 56, 249.

2. Mannick, J. A., and R. H. Egdahl. Ribonucleic acid in "transformation" of lymphoid cells. Science 1962, 137, 976.

3. Mannick, J. A., and R. H. Egdahl. Transformation of nonimmune lymph node cells to state of transplantation immunity by RNA. A preliminary report. Ann. Surg. 1962, 156, 356.

4. Brent, L., J. Brown, and P. B. Medawar. Skin transplantation immunity in relation to hypersensitivity. Lancet 1958, 2, 561.

5. Clarke, S. D., and R. E. Wilson. Localization of RNA responsible for direct transfer activity. Surg. Forum 1963, 14, 150.

6. Najarian, J. S. Discussion of Mannick, J. A. Transfer of "adoptive" immunity to homografts by RNA. A preliminary report. Surgery 1964, 56, 254. 
7. McMaster, P. R. B. Personal communication.

8. Dvorak, H. F., and B. H. Waksman. Primary immunization of lymph node cells in Millipore chambers by exposure to homograft antigen. J. exp. Med. 1962, 116, 1.

9. Mannick, J. A. Inhibition by RNA of the transfer reaction following homograft sensitization. J. clin. Invest. 1964, 43, 740.

10. Hotchkiss, R. D. Characterization of nucleic acids by spectrophotometry in Methods in Enzymology, S. P. Colowick and N. O. Kaplan, Eds. New York, Academic Press, 1957, vol. 3, p. 710.

11. Snedecor, G. W. Statistical Methods Applied to Experiments in Agriculture and Biology. Ames, Iowa, Iowa State University Press, 1956, p. 90.

12. Mannick, J. A. Unpublished observations.

13. Jankovic, B. D., and H. F. Dvorak. Enzymatic inactivation of immunologically competent lymph node cells in the "transfer reaction." J. Immunol. 1962, 89, 571.

14. Najarian, J. S., and J. D. Feldman. Passive transfer of transplantation immunity. IV. Transplantation antibody from extracts of sensitized lymphoid cells. J. exp. Med. 1963, 118, 759.

15. Nester, M., O. Mäkelä, and G. J. V. Nossal. Studies on the transfer of nucleoprotein fractions from immunized spleens. Transplant. Bull. 1961, 28, 98.

16. Billingham, R. E., L. Brent, and P. B. Medawar. Extraction of antigens causing transplantation immunity. Transplant. Bull. 1958, 5, 377.

17. Kandutsch, A. A. The chemistry of transplantation antigens. A review. Transplant. Bull. 1961, 27, 135.

18. Mannick, J. A., J. T. Graziani, and R. H. Egdahl. A transplantation antigen recovered from cell culture medium. Transplantation 1964, 3, 321.

19. Jacob, F., and J. Monod. Genetic regulatory mechanisms in the synthesis of proteins. J. molec. Biol. 1961, 3, 318.

20. Billingham, R. E., L. Brent, and P. B. Medawar. Quantitative studies on tissue transplantation immunity. II. The origin, strength and duration of actively and adoptively acquired immunity. Proc. roy. Soc. B 1954, 143, 58.
21. Mitchison, N. A. Studies on the immunological response to foreign tumor transplants in the mouse. I. The role of lymph node cells in conferring immunity by adoptive transfer. J. exp. Med. 1955, $102,157$.

22. Woodruff, M. F. A., and M. O. Symes. The use of immunologically competent cells in the treatment of cancer: experiments with a transplantable mouse tumor. Brit. J. Cancer 1962, 16, 707.

23. Warwick, W. J., O. K. Archer, and R. A. Good. Effect of previous homograft on passive transfer of delayed allergy. Ann. N. Y. Acad. Sci. 1962, 99, 620.

24. Fishman, M., and F. L. Adler. Antibody formation initiated in vitro. II. Antibody synthesis in $\mathrm{X}$-irradiated recipients of diffusion chambers containing nucleic acid derived from macrophages incubated with antigen. J. exp. Med. 1963, 117, 595.

25. Fishman, M., R. A. Hammerstrom, and V. P. Bond. In vitro transfer of macrophage RNA to lymph node cells. Nature (Lond.) 1963, 198, 549.

26. Fishman, M. Discussion in Immunopathology. Third International Symposium, P. Grabar and P. A. Miescher, Eds. New York, Grune \& Stratton, 1963, p. 137.

27. Lawrence, H. S. The transfer of hypersensitivity of the delayed type in man in Cellular and $\mathrm{Hu}$ moral Aspects of the Hypersensitive States, H. S. Lawrence, Ed. New York, P. B. Hoeber, 1959, p. 279.

28. Lawrence, H. S., F. T. Rapaport, J. M. Converse, and W. S. Tillet. Transfer of delayed hypersensitivity to skin homografts with leukocyte extracts in man. J. clin. Invest. 1960, 39, 185.

29. Lawrence, H. S., S. Al-Askari, J. David, E. C. Franklin, and B. Zweiman. Transfer of immunological information in humans with dialysates of leukocyte extracts. Trans. Ass. Amer. Phycns 1963, 76, 84.

30. Fong, J., D. Chin, and H. M. Vickrey. Studies of tubercle bacillus-histiocyte relationships. VII. Homologous and heterologous transfer of cellular resistance. J. exp. Med. 1963, 118, 727. 